\title{
Effectiveness of Carbon Monoxide Concentration Reduction on Active Carbon Contact System in Burning Polystyrene Foam
}

\author{
Elanda Fikri ${ }^{1 *}$, Aprilia Veronica ${ }^{2}$ \\ 1 Department of Environmental Health, Bandung Health Polytechnic, Cimahi Utara, 40514, Doctorate Program \\ of Environmental Studies, Diponegoro University, Semarang, Indonesia \\ 2 Department of Environmental Health, Bandung Health Polytechnic, Cimahi Utara, Indonesia \\ * Corresponding author's e-mail: elandafikri@yahoo.com
}

\begin{abstract}
One of the wastes generated by PT Beton Elemenindo Perkasa is polystyrene foam waste. Processing of this type of waste is still done with open burning so it has an impact on health and the environmental quality degradation. One of the polystyrene foam waste processing technologies is by constructing a combustion furnace equipped with carbon filter. Activated carbon is one of the air filter media that can absorb harmful gases from the combustion process. The purpose of this research is to identify the effectiveness of carbon monoxide (CO) concentration reduction on active carbon contact system using variation of particle size. This research is a kind of an experimental study involving post test with control design. The number of samples was calculated based on the number of treatments and the number of repetitions in the study. This research used 2 kinds of treatment, including 20 mesh and 30 mesh in 9 repetitions. Independent T-Test statistical analysis showed a significant difference $(p$-value $=0.001)$ between the variation of particle size of activated carbon and the CO parameters with the average of the most effective reduction percentage on particle-sized active carbon of 30 mesh was $77.95 \%$.
\end{abstract}

Keywords: polystyrene foam, particle size, activated carbon, carbon monoxide

\section{INTRODUCTION}

National development in the economic field is implemented in order to create a strong economic structure through the development of advanced industries as an economic driving force supported by strength and resilience of resources. According to Law No. 3 in 2014 regarding industry, industry comprises all forms of economic activities that process raw materials and/or utilize industrial resources to produce goods that have added value or higher benefits, including industrial services.

The development of industry in Indonesia is currently increasing, in line with the development of science and for the fulfilment of human needs, but the industry also contributes to the environmental pollution if the waste of industrial activities is not managed properly (Fikri et al., 2015). Industry is always connected with the environmental pollution problem, especially related to the process of industrial activities. Industrial activities initially intended to improve the quality of human life; however, they can be detrimental to the human survival (Danarto et al, 2008).

Broadly speaking, waste comes from the pollution caused by industries and domestic sectors that generate domestic waste. Increased waste production in 2017 cannot yet be balanced with proper processing. Waste becomes a problem especially in the urban areas, where the amount of waste produced can reach about 1,311 tons per day. These types of waste come from household and industrial waste. Waste is divided into two types, namely organic and inorganic waste. The organic waste is a waste that can be broken down by nature. Conversely, the inorganic waste is a waste that is difficult to decompose or even cannot be decomposed naturally. The inorganic waste has become part of the community. One example is styrofoam. Styrofoam is widely used by society 
as food wrappers. However, it can cause environmental pollution because it is thrown away after use (Wicaksono, 2011).

Polystyrene foam is widely known as Styrofoam, which is often used inappropriately by the public because styrofoam is actually a trade name that has been patented by Dow Chemical company. Styrofoam is intended for use as an insulator on building construction materials, not for food packaging. Polystyrene foam package is chosen as it is lightweight, capable of maintaining the temperature of hot/ cold food and hold it comfortably, keeping the food freshness. Due to these advantages, polystyrene foam packaging is used to package readyto-eat, fresh foods, or the foods that require further processing. Many fast food restaurants serve their dishes using these packages, as well as other food products such as instant noodles, chicken porridge, meatballs, coffee, and yogurt (Fitrianti et al, 2016).

Solid waste requires serious attention because it can pose a threat during handling until its destruction (Fikri et al., 2016). The lack of attention in waste management resulting from industrial activities is one of the causes of environmental pollution; hence it requires a process of waste treatment to reduce environmental pollution from industrial waste. One way that can be used to overcome these problems is by processing the combustion chamber furnace unit equipped with an air filter. Processing can reduce the volume of solids (Jamilatun et al, 2014).

Beton Elemenindo Perkasa Company is a business engaged in the field of construction. The industry produces organic and inorganic waste that is still not disposed of properly, which is by burning waste in the open space without the any control, so that the burning produces smoke. Domestic waste produced in PT.BEP also includes leftover food, plastic, and styrofoam food container. Waste control, especially pertaining to Styrofoam, can be done physically, chemically, and technically. The physical control involves using styrofoam as a basic material for children's toys and handicraft, while the chemical control can be done by using essential oil from orange peel to break down styrofoam waste; finally, the technical control can be done by carrying out the burning process (Fitrianti et al., 2016). The result of Focus Group Discussion with the company revealed that one of the most effective and feasible ways to do styrofoam waste treatment is by applying the technical solution, i.e. burning. However, it is required to control the exhaust generated from the combustion process.

Burned styrofoam waste can produce harmful gases such as styrene, hydrochloroflourocarbon (HCFC), polycyclic aromatic hydrocarbons (PAHs), carbon black, and carbon monoxide. When styrofoam is being burned, carbon monoxide is released into the air. According to the US Environmental Protection Agency (EPA), carbon monoxide is an undetectable gas that can harm human health. The exposure to carbon monoxide can cause fainting, dizziness, and nausea. Carbon monoxide is one of the most dangerous chemicals as a result of the burning of styrofoam (Kurniati, 2008).

The control of air pollution can be done by using adsorbents such as activated carbon and zeolite (Yuliusman, 2013). Zeolites contain great quantities of impurities that can reduce the surface area; if used directly, they can clarify the smoke. The capability of yeolites to absorb water vapor is greater than absorbing $\mathrm{CO}$ so that the adsorption capacity is reduced. Activated carbon is an adsorbent that has the highest $\mathrm{CO}$ absorbing ability as it has a better surface area than other adsorbents.

\section{MATERIALS AND METHODS}

This type of research is an experimental, with post test design with control group (Postest with control design). In this study, there were two groups of subjects, one was subjected to treatment (experimental group) and the other one was not treated (control group). On the basis of this design, the effect of the treatment on the dependent variable will be tested by comparing the state of dependent variable in the experimental group after treatment with the untreated control group. In this experiment, the subjects were presented with several treatments and then the results were measured (Notoatmodjo, 2012). The strategy in controlling the confounding variables in this study was:

- Temperature - to control the confounding variables, the temperature applied in this research was $150^{\circ} \mathrm{C}$.

- Volume of furnace - to control the confounding variables, the furnace volume was adjusted to the amount of polystyrene foam waste. 


\section{Sample}

The sample size in the study was obtained based on the experimental, completely randomized design. The sample size determined in this study was based on the number of treatments. The treatments used in this study involved variations of the size of active carbon (20 mesh and 30 mesh) with 9 repetitions (Gomez, 2007). The employed polystyrene foam sampling technique was non random purposive sampling, involving polystyrene foam used as food container with the weight about $8 \mathrm{gr} /$ container.

Total polystyrene foam to be taken was:

- (2 treatments $\times 70$ samples of polystyrene foam used as food container) $\times 9$ repetitions + control;

- (140 samples of polystyrene foam used as food container) $\times 9$ repetitions +9 control $\times$ (70 samples of polystyrene foam used as food container);

- $(1260+630)$ samples of polystyrene foam used as food container;

- 1890 samples of polystyrene foam used as food container.

\section{Procedures}

The first step was designing furnace as a combustion chamber with $25 \mathrm{~cm}$ chimney's diameter as well as preparing the tools and materials. The side of the stove is cut to make the door for garbage introduction and place for fuel. The door was welded in order to close the connection. The air filter media was prepared by crushing the activated carbon by using pestle. Crushed pounded carbon was then filtered to the required size of 20 mesh and 30 mesh.

\section{RESULTS AND DISCUSSION}

Table 1 shows the lowest temperature is $46.4^{\circ} \mathrm{C}$ and the highest temperature is $38.1^{\circ} \mathrm{C}$; the lowest humidity is $39 \%$ and the highest humidity is $30 \%$; and the lowest wind speed is $1.71 \mathrm{~m} / \mathrm{s}$ and the highest wind speed is $1.07 \mathrm{~m} / \mathrm{s}$. The measurement results of carbon monoxide concentration are presented in Table 2.

The average concentration of carbon monoxide is $194 \mathrm{ppm}$, found in the filter media with 30 mesh particle-sized active carbon and the highest average concentration of $878 \mathrm{ppm}$ is in the
Table 1. Temperature, humidity, and wind speed

\begin{tabular}{|c|l|c|c|}
\hline No & Variable & Minimum & Maximum \\
\hline 1 & Temperature & $38.1^{\circ} \mathrm{C}$ & $46.40^{\circ} \mathrm{C}$ \\
\hline 2 & Humidity & $30 \%$ & $39 \%$ \\
\hline 3 & Wind Speed & $1.07 \mathrm{~m} / \mathrm{s}$ & $1.71 \mathrm{~m} / \mathrm{s}$ \\
\hline
\end{tabular}

Table 2. Carbon monoxide concentration

\begin{tabular}{|c|c|c|c|}
\hline Repetition & $\begin{array}{c}\text { Control } \\
(\mathrm{ppm})\end{array}$ & $\begin{array}{c}20 \text { Mesh } \\
(\mathrm{ppm})\end{array}$ & $\begin{array}{c}30 \text { Mesh } \\
(\mathrm{ppm})\end{array}$ \\
\hline 1 & 860 & 200 & 161 \\
\hline 2 & 870 & 295 & 183 \\
\hline 3 & 879 & 360 & 197 \\
\hline 4 & 892 & 311 & 192 \\
\hline 5 & 898 & 319 & 195 \\
\hline 6 & 918 & 339 & 213 \\
\hline 7 & 853 & 273 & 172 \\
\hline 8 & 860 & 341 & 204 \\
\hline 9 & 871 & 366 & 226 \\
\hline Average & 878 & 312 & 194 \\
\hline Maximum & 918 & 366 & 226 \\
\hline Minimum & 853 & 200 & 161 \\
\hline Std Dev & 21.16 & 51.46 & 19.97 \\
\hline
\end{tabular}

control. On the basis of the results, the lowest concentration of $\mathrm{CO}$ is when air filter medium is passing through size 30 mesh, yielding the concentration of $161 \mathrm{ppm}$.

The research conducted by Basuki et al (2008) showed that the most effective thickness of air filter media is $15 \mathrm{~cm}$ with the percentage of $\mathrm{CO}$ reduction of $83.90 \%$. On the basis of the research conducted by Ardiani et al. (2008), the effective use of activated carbon is $15 \mathrm{~cm}$ with the percentage of $\mathrm{CO}$ reduction of $70.83 \%$. The size of the utilizied activated carbon particles is 20 mesh, 30 mesh, and 40 mesh. On the basis of the previous research, the most effective particle size of the activated carbon is 30 mesh, because 40 mesh particle size produces dust when being passed by activated carbon filter media. Therefore, the variation of particle size in the research includes only 2 kinds, that is 20 mesh and 30 mesh.

Table 3 shows the reduction difference in $\mathrm{CO}$ concentration in the air filter media of the active carbon with the particle size of 20 mesh and 30 mesh. The average reduction of $\mathrm{CO}$ concentration in air filter media of 20 mesh active carbonwas $566 \mathrm{ppm}$ (64.54\%); on the other hand, in the air filter media with 30 mesh active carbon, the reduction amounted to $684 \mathrm{ppm}(77.95 \%)$. The results of the Independent T-test also showed significant 
Table 3. Reduction difference and reduction percentage in carbon monoxide concentration

\begin{tabular}{|c|c|c|c|c|}
\hline \multirow{2}{*}{ Repetition } & \multicolumn{2}{|c|}{ Reduction Difference } & \multicolumn{2}{c|}{ Reduction Percentage } \\
\cline { 2 - 5 } & 20 Mesh $(\mathrm{ppm})$ & 30 Mesh $(\mathrm{ppm})$ & 20 Mesh $(\mathrm{ppm})$ & 30 Mesh $(\mathrm{ppm})$ \\
\hline 1 & 661 & 699 & $76.79 \%$ & $81.29 \%$ \\
\hline 2 & 575 & 687 & $66.09 \%$ & $78.97 \%$ \\
\hline 3 & 519 & 681 & $59.03 \%$ & $77.54 \%$ \\
\hline 4 & 581 & 700 & $65.13 \%$ & $78.51 \%$ \\
\hline 5 & 580 & 703 & $64.53 \%$ & $78.29 \%$ \\
\hline 6 & 578 & 705 & $63.02 \%$ & $76.79 \%$ \\
\hline 7 & 580 & 681 & $68.00 \%$ & $79.84 \%$ \\
\hline 8 & 518 & 656 & $60.29 \%$ & $76.31 \%$ \\
\hline 9 & 505 & 645 & $58.02 \%$ & $74.01 \%$ \\
\hline Average & 566 & 684 & $64.54 \%$ & $77.95 \%$ \\
\hline
\end{tabular}

differences in the $\mathrm{CO}$ concentration reduction for variations of particle-sized active carbon with $\mathrm{p}$ value of 0.001 (Table 4 ).

Activated carbon has been widely used as an air filter media in previous studies. On the basis of the research conducted by Maryanto et al. (2009), the average percentage of carbon monoxide reduction was by using activated carbon $45.68 \%$, $70.83 \%$ (Ardiani et al., 2016), and 83.90\% (Basuki et al., 2008). Chemical adsorbents (in the form of activated carbon / activated charcoal) can theoretically be used to reduce air pollutants. Activated carbon is a carbon compound that has increased its adsorption power by activation process (Jamilatun et al., 2014). In the activation process, the removal of hydrogen, water, and gas from the carbon surface occurs so that there is a physical change on the surface. Activation occurs because the active group formed due to the interaction of free radicals on the carbon surface with atoms such as $\mathrm{O}_{2}$ and $\mathrm{N}_{2}$. In the activation process, new pores were also formed due to the erosion of carbon atoms through oxidation/heating.

New pores on activated carbon create a broad and hollow surface with a layered structure. The pores can absorb gas, so that the gas passing through the activated carbon will be bonded and subjected to a pulling force with active carbon pores. On the basis of the previous research, activated carbon can absorb the NOx gas (Jaya, 2014, Verlina, 2014) and CO (Basuki, 2008; Maryanto, 2009; Jaya, 2014; Verlina, 2014; Ardiani, 2016; Nurullita, 2015).

The carbon monoxide gas generated from the furnace combustion process will accumulate on the adsorbent surface. The formation of new pores of activation further expands the surface of the activated carbon creating more areas adsorbing the materials outside. Furthermore, the $\mathrm{CO}$ gas
Table 4. Independent test results T-test

\begin{tabular}{|c|c|c|c|}
\hline \multirow{2}{*}{ Class } & \multicolumn{2}{|c|}{$\begin{array}{c}\text { Levene's Test for } \\
\text { Equality of Variances }\end{array}$} & $\begin{array}{c}\text { t-test for Equality of } \\
\text { Means }\end{array}$ \\
\cline { 2 - 4 } & $\mathrm{F}$ & Sig & Sig (2 tailed) \\
\hline $\begin{array}{c}\text { Equal } \\
\text { variances } \\
\text { assumed }\end{array}$ & 3.602 & 0.076 & 0.001 \\
\hline $\begin{array}{c}\text { Equal } \\
\text { variances not } \\
\text { assumed }\end{array}$ & & 0.001 \\
\hline
\end{tabular}

accumulated on the surface of the adsorbent will be absorbed by the adsorbent (Nurullita, 2015).

In the control group, in which no ingredients were given, the $\mathrm{CO}$ gas does not absorb but only accumulates in the air. In the treatment group, the filter media were given different size of activated carbon particles, i.e. 20 mesh and 30 mesh. The $\mathrm{CO}$ gas has different absorption on each size of activated carbon particles. For that reason, there

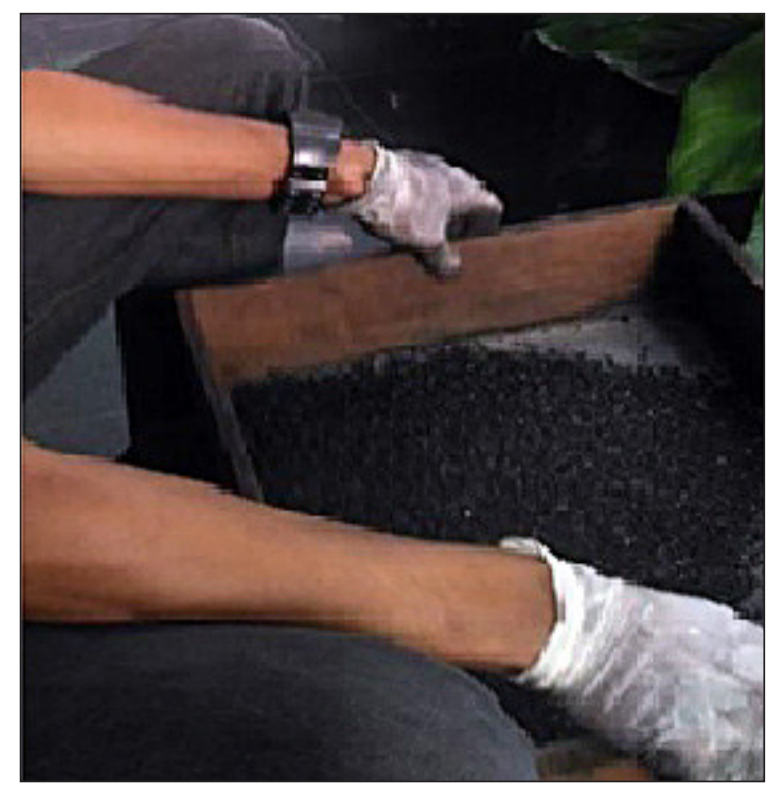

Fig. 1. Active Carbon Filter 20 mesh and 30 mesh 


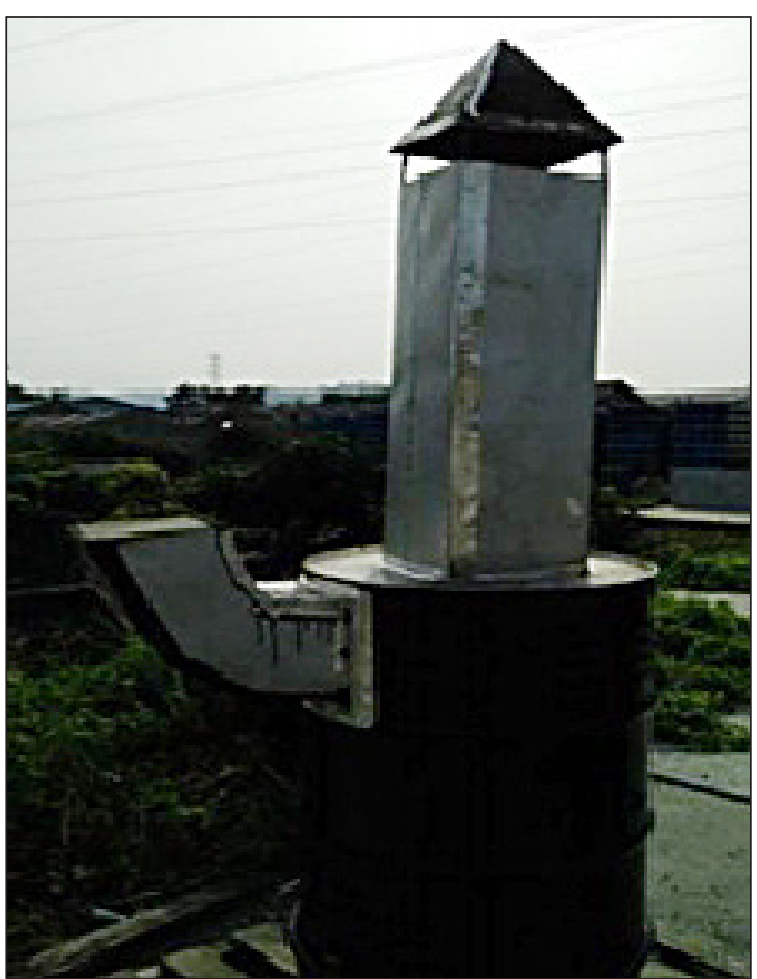

Fig. 2. Furnace

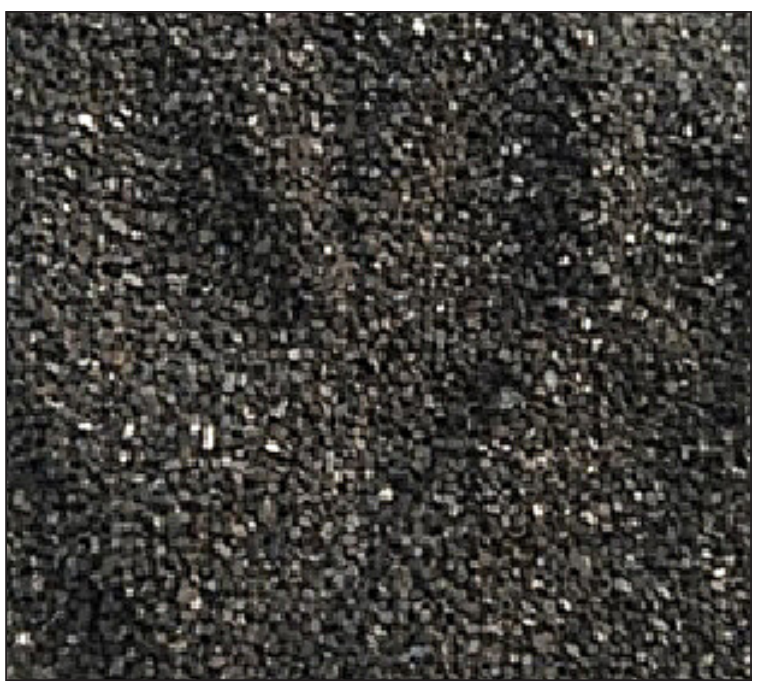

Fig. 3. Size of Activated Carbon Particles 20 Mesh

is a difference of $\mathrm{CO}$ gas concentration on each size of activated carbon particles.

The difference in the $\mathrm{CO}$ gas concentration reduction between 20 mesh and 30 mesh particle-sized active carbon is due to different surface area. Therefore, the surface area can affect the absorption of carbon monoxide because the greater the surface area of activated carbon, the more $\mathrm{CO}$ will be adsorbed. A filter medium that is capable of absorbing a lot of carbon monoxide (CO) is the one with a particle size of 30 mesh

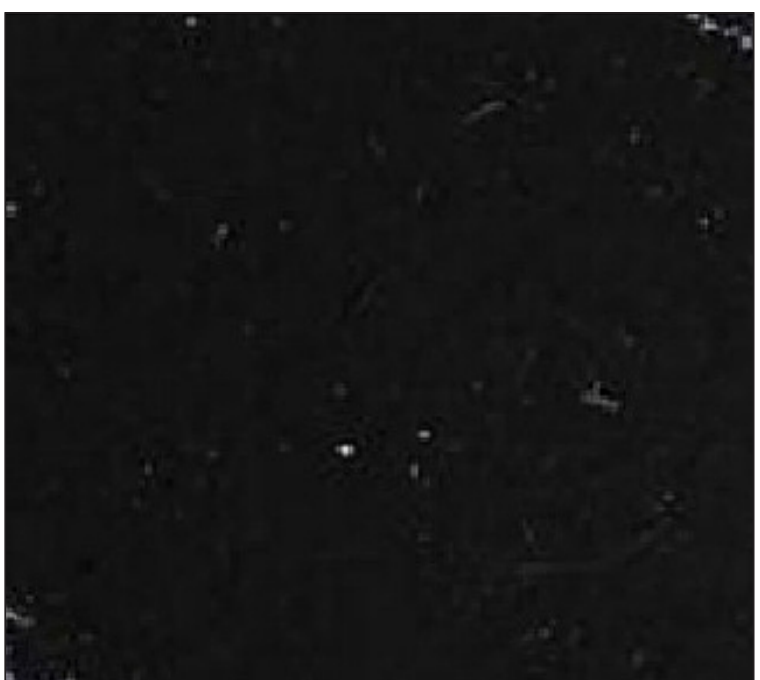

Fig. 4. Size of Activated Carbon Particles 30 Mesh

active carbon, hence, the smaller the size of the activated carbon, the higher the absorption or the less $\mathrm{CO}$ is produced.

The activated carbon used comes from the coconut shell to absorb the material in the form of steam or gas. The pores present in the type of char are micropores that cause the gas molecules to pass through; however, the molecules of the liquid cannot pass through.

Several factors that may affect the absorption capacity of activated carbon are the physical properties of the activated carbon and the properties corresponding to the number and size of the pores that can be filled by the adsorbate. Each molecule will fill the pores according to its size. The chemistry of activated carbon also affects the absorption of activated carbon because the activating groups on its surface can interact chemically with organic molecules. The presence of Van der Waals forces on the surface of the activated carbon of the adsorbate enables the adsorption process (Khairunisa, 2008).

The chemical properties of the activating groups in the activated carbon are produced at the time of activation. This functional group makes the surface of activated carbon chemically reactive and affects the nature of adsorption (Subekti, 2009). The saturation time of the air filter media used in this study is not known, so the use of air filter media use should be noted because it can affect the effectiveness of carbon monoxide concentration reduction. On the basis of the research by Basuki et al. (2008), the saturation time of activated carbon with the thickness of $15 \mathrm{~cm}$ is 45.84 hours. 


\section{CONCLUSION}

1. There is a difference in the carbon monoxide concentration with variation of particle sizes of activated carbon in polystyrene foam burning process with $\mathrm{p}$-value of 0.001 .

2. The average reduction percentage of carbon monoxide concentration in air filter media of 20 mesh particle-sized active carbon was $64.54 \%$ (566 ppm) and 30 mesh $-77.95 \%$ (684 ppm). This means that the active carbon with the particle size of 30 mesh is quite effective in lowering the concentration of $\mathrm{CO}$ in the burning process of polystyrene foam waste.

\section{Acknowledgements}

This study was financially supported by Unit Penelitian dan Pengabdian Masyarakat (UPPM) Poltekkes Kemenkes RI Bandung, Ministry of Health, Indonesia scheme.

\section{REFERENCES}

1. Ardiani Y., Dwi T., Achmad T. 2016. Reduce the concentration of carbon monoxide from mainstreams cigarette smoke by using coconut sehll activated carbon filter. International Journal of Current Research, 8 (8), 35586-35591.

2. Basuki K. T. 2008. Reduction of CO and NO2 concentrations on exhaust emissions by using local inhibitor TiO2 media on activated carbon. JFN 1(1), 45-64.

3. Danarto Y.C., Samun, T. 2008. The effect of carbon activation of rice husk on the metal adsorption process of $\mathrm{Cr}$ (VI). Ekuilibrium, 7(1), 13-16.

4. Fikri, E., Purwanto., Henna, R.S. 2015. Modelling of household hazardous waste (HHW) management in Semarang City (Indonesia) by using life cycle assessment (LCA) approach to reduce greenhouse gas (GHG) emissions. Procedia Environmental Science, 23(2015), 123-129.

5. Fikri, E., Purwanto., Henna, R.S. 2016. Life cycle assessment of household hazardous waste management options for Semarang City, Indonesia. Int. J. Environ- ment and Waste Management, 17(2), 146-157.

6. Fitrianti A.E. 2016. Determination of the essential oil level of the sunkist orange peel (citrus sinensis 1. Osbeck) as an alternative to natural styrofoam. Indonesian Journal of Pharmaceutical Science, 3(2), 47-52.

7. Jamilatun, S., Martomo S. 2014. Making of activated charcoal from coconut shell and its application for liquid smoke purification. Spektrum Industri. 12(1), 1-14.

8. Jaya F.T., 2014. Adsorption of CO, NO, and NOx emissions using activated carbon from cocoa fruit leaf waste (Theobroma cacao L.) on four-wheeled vehicles, Makassar. Ph.D. Thesis, Hasanudin University, Makasar.

9. Khairunisa R. 2008. The combination of electrolysis and adsorption techniques uses activated carbon to decrease the concentration of phenol compounds in water. Ph.D. Thesis, Universitas Indonesia, Jakarta.

10. Kurniati. 2008. Utilization of oil palm shells as activated charcoal. Jurnal Penelitian Ilmu Teknik, 8(2), 96-103.

11. Maryanto. 2009. Decrease in carbon monoxide (CO) emissions by addition of activated charcoal to motor vehicles in Yogyakarta. Jurnal Fakultas Kesehatan Masyarakat, 3(3), 198-205.

12. Notoatmodjo S. 2012. Health research methodology. Rineka Cipta, Jakarta.

13. Nurullita U., Mifbakhuddin. 2015. Adsorbtion of indoor carbon monoxide (CO) gas with coconut shell activated carbon and durian skin, semarang. The 2nd University Research Coloquium, 297-306.

14. Subekti P. 2009. Effect of the use of exhaust gas absorbing media on air pollution control devices for diesel-engined vehicles, riau. APTEK, 1(1), 1-11.

15. Verlina W.O.V. 2014. The potential of coconut shell activated charcoal as an adsorbent of $\mathrm{CO}, \mathrm{NO}$, and NOx gas emissions in motor vehicles, Makassar. Ph.D. Thesis, Universitas Hasanudin, Makasar.

16. Wicaksono B. 2011. Processing waste styrofoam, orange peel, and sanseveiria fibers into synthetic yarns of economic value. Ph.D. Thesis, Institut Pertanian Bogor, Bogor.

17. Yuliusman W., Wahyu P., Yulianto S.N. 2013. Selection of adsorbents for carbon monoxide adsorption using isothermal langmuir adsorption model. Reaktor, 14(3), 225-233. 